\title{
Empirical Evidence on Capital Structure Determinants in Jordan
}

\author{
Aziz N. Yusuf ${ }^{1}$, Ali M. Al-Attar ${ }^{2}$ \& Husni K. Al-Shattarat ${ }^{3}$ \\ ${ }^{1}$ Department of Banking and Finance, American University of Madaba, Jordan \\ ${ }^{2}$ Department of Accounting, German Jordanian University, Jordan \\ ${ }^{3}$ Department of Accounting, Zarqa Private University, Jordan \\ Correspondence: Aziz N. Yusuf, Department of Banking and Finance, American University of Madaba, P.O. Box \\ 2882, Amman 11821, Jordan. E-mail: a.yusuf@aum.edu.jo
}

Received: June 18, 2014

doi:10.5539/ijbm.v10n5p134

\author{
Accepted: April 7, 2015 \\ Online Published: April 20, 2015 \\ URL: http://dx.doi.org/10.5539/ijbm.v10n5p134
}

\begin{abstract}
This study investigates the relationship between firm characteristics and corporate governance, and capital structure in Jordanian companies listed on the Amman Stock Exchange (ASE). The data consisted of 344 observations spanning over a period of six years. Following previous studies, the observations were analyzed using STATA to run pooled, random and fixed effect regressions on decomposed debt models. This study finds that given their internal nature, Jordanian firms are influenced by both firm specific factors and corporate governance which provides them with better access to short-term debt consequently reducing agency problems and the risk of refinancing.
\end{abstract}

Keywords: capital structure, corporate governance, decomposed debt models, random and fixed effect, Jordan

\section{Introduction}

The Modigliani-Miller (1958) theorem, forms the basis for modern thinking on capital structure, examining real world reasons of why capital structure is relevant, that is, that a company's value is affected by the capital structure it employs. Since then, a rich theoretical literature has emerged that sculpts a firm's capital structure choice under different assumptions. However, very little is known about the empirical relevance of the different theories. Since then, numerous studies have advocated these theories and modified them to incorporate more realistic and fundamental factors, such as corporate and personal taxes (Miller, 1977), bankruptcy costs (Myers \& Pogue, 1974), and agency costs (Jensen \& Meckling, 1976), formulating the 'Trade-off Theory'; information asymmetry, or the 'Signalling Theory' (Ross, 1977); and Myers and Maljuf (1984) who elaborated and brought out the 'Pecking Order Theory' originally developed by Donaldson (1961) (Note 1).

An extensive amount of the empirical research so far has been largely confined to large publicly listed companies in the United States and other international capital markets (Gleason et al., 2000; Zingales, 2000; Myers, 2001: Ozkan, 2001; Antoniou et al., 2002; Devan \& Danpolt, 2002; Karmel \& Bryon, 2002 ). Booth et al. (2001) were one of the first researchers to study the topic of capital structure in developing countries (Note 2) suggesting that similar factors which affected capital structure in developed countries also affected those in developing countries. This spurred subsequent research such as that of Pandey (2001) for instance, who examined the capital structure of Indian firms, while Sukkari (2003) and Buferna et al. (2005) investigated the determinants of capital structure in Kuwaiti and Libyan companies. Furthermore, Alsadeek (2001) also examined the financial structure of industrial companies in Saudi Arabia and Kharawish (2008) examining the financial structure of commercial banks in Egypt.

The finding of these and other studies are relevant as evidence on the capital structure puzzle in Jordanian firms. A few recent studies have attempted the case of Jordan by examining the determinants of capital structure in listed Jordanian industrial companies (Deranieh, 1992; Omet \& Nobanee, 2001; Alkhasawneh, 2006; Slash et al., 2006; Zeitun \& Tian, 2007; Kharawish, 2008; Al-Najjar, 2011; Al Shaher, 2012; Soumadi \& Hayajneh, 2012).

This study examines the capital structure behavior of Jordanian companies in light of the effects of a combination of corporate factors. These factors include the more commonly used factors such as Asset Structure, Liquidity, Profitability, Firm Size, Firm Growth, Firm Risk and Non-debt Tax Shields. Furthermore, less conventionally used factors adopted from recent literature such Ownership Structure, Board Size, CEO/Duality 
and Non-executive structure were also included. The study further decomposes debt into long-term and short-term debt because according to Bevan and Danbolt (2002), determinants of leverage based on total debt may disguise the significant differences between these decompositions. The scheme developed for this study follows practices of previous studies and covers a study period spanning 6 years, namely from 2006 to 2011 as panel data. The reason for choosing this particular scheme was because it reflects significance of the time period in which the companies operated and social and economic conditions that were present during this time.

\section{Literature Review}

The main ground upon which capital structure theory was initially developed mainly concerned the large listed firms. Initially, the Pecking Order Theory (POT) sought to explain the observed financing practices of large publicly traded corporations and is in keeping with the notion that debt is by far the largest source of external finance for many businesses. In relation to the owner-manager's control over operations and assets, if the 'Pecking Order Theory' holds, then internal equity finance will be preferred, because it does not surrender control thereby reducing agency costs and lowering floatation and information costs compared to new equity financing (Grier \& Zychowicz, 1994; Bathala et al., 1994; Alkhasawneh, 2006).

When firms grow and exhaust their supply of funds and resort to selling equity, a new form of cost arises, namely agency costs. Van der Wijst (1989) and Ang (1992) claim that agency conflicts between shareholders and lenders may be particularly severe, and therefore to minimize the cost of many externally contracted transactions would be another reason why firms prefer internal over external financing (Coase, 1937; Williamson, 1975). Hence, as the number of contracts a firm writes increase, the firm usually grows.

Furthermore, asymmetric information can be applied in the notion of growth potential providing signals of company performance. Growth causes variations in the value of a firm where larger variations are often interpreted as greater business risk (Bhaduri, 2002). Thus, a firm is likely to employ less debt in its capital structure (Daskalakis \& Psillaki, 2008). Furthermore, the cash flows of a firm whose value is most likely to remain stable in the future is predictable, and its capital requirements can be financed with more debt more easily than those of a firm with growth potential (Psillaki \& Mondello, 1996). Myers (1977) supports this by stating that firms with growth potential will tend to have lower leverage.

Theory and practice have many times proven that when it comes to financial distress, the size of the firm is an important factor. Warner (1977), Ang et al. (1982) and Pettit and Singer (1985) have found that larger firms tend to be more diversified and go bankrupt less often than smaller firms. Therefore, larger firms are able and expected to employ more debt than smaller ones. Petersen and Rajan $(1994 ; 1995)$ affirmed that the total borrowing ratio decreases with age and increases with size. This is the same as stating that younger firms are more likely to turn to finance companies with third-party resources, whereas larger firms are self-financed (Berger \& Udell, 1992; 1995; Cardone et al., 1998).

The type of assets that a firm possesses can also be considered an ambiguous factor that contributes in the determination of the debt-equity ratio. Specifically, the costs of financial distress depend on the type of assets that a firm has (Note 3). Scott (1976) argues that a firm determining the optimal capital structure will issue as much secured debt as possible, because the agency costs of secured debt are lower than those of unsecured debt. Securable assets are considered to be tangible assets such as plant and equipment and thus, firms with more tangible assets should issue more debt (Titman \& Wessels, 1988; Rajan \& Zingales, 1995; Booth et al., 2001). Furthermore, a sizable amount of tangible assets may indicate that a firm has already found a stable source of return which provides it more internally generated funds and prohibits it from turning to external financing. A negative relationship between leverage and asset structure can also be an indication that the pecking order exists.

Finally, since the late 1990's, extra emphasis was placed on the mechanisms of corporate governance and their influence on capital structure decisions. A few studies for instance have explained the positive significance of Board Size, suggesting that firms with high debt ratios may have greater advising and monitoring requirements (Jensen, 1986; Wen et al., 2002; Coles et al., 2008), and so firms with larger board sizes have lower costs of debt (Anderson et al., 2003).

Also institutional ownership seems predominant in emerging markets (Manawaduge et al., 2009) and as explained by Lee (2010), due to the nature of the undeveloped equity markets and lack of safeguard for domestic investors. On the other hand, Pushner (1995), Grier and Zychowicz (1994), and Tong and Ning (2004) explain that institutional investors prefer low leveraged firms as they signal lesser prospects of financial problems. Furthermore, due to the monitoring, intervention, the disciplinary influence it brings with it, institutional ownership can generate internal funds thereby reducing the need for external borrowing (Agca \& Mansi, 2008). 
Arbor (2007) and Fosberg (2004) find that the relationship between CEO duality and a company's capital structure to be positive, explaining that duality leadership reduces problems related to separation of ownership and control and can lead to higher access to external debt (Faleye, 2004).

In addition, a few studies have indicated to a positive association of non-executive directors with firm leverage. As Jensen (1986), Berger et al. (1997) and Abor (2007) point out, non-executive directors have a positive impact on corporate leverage ensuring management accountability of shareholders, and therefore, the more a firm has in terms of outside directors, the more a firm is protected against uncertainties and thereby increases its' ability to raise external funds (Pfeffer, 1973) and Pfeffer and Salancick (1978). On the other hand, Wen et al. (2002) argued that as firms have more outside non-executives, the more prone firms are to actively strict monitoring, which may entice them to adopt lower external financing policies.

The following section examines in more detail the relationship between the predictors chosen and the different maturities of leverage upon which the hypotheses of this study were developed.

\section{Hypotheses Development}

The variables chosen to represent the explanatory side to capital structure follows a mix of work from past and present literature and includes Asset Structure, Firm Size, Firm Growth, Profitability, Liquidity, Firm Risk, Ownership Structure, CEO Duality, Board Size, and Non-executive structure upon which the hypotheses are developed. Moreover, just as important as the influence of these predictors have on total leverage, the examination of short and long-term debt may reveal important results.

In its many years of use, asset structure has been the predominant factor in explaining the financial behaviour of firms in corporate literature. Specifically, the use of tangible assets as collateral can reduce creditor's risk and also increases asset value in case of liquidation and bankruptcy. According to Booth et al. (2001), tangible assets not only increase a firm's ability to issue secured debt but also provide less information about future profits. Therefore, firms whose assets are suitable as security for loans tend to use debt rather heavily and various studies have confirmed such positive associations with asset structure (Myers, 1977; Scott, 1977; Cassar \& Holmes, 2003; Harris \& Raviv, 1991; Titman \& Wessels, 1988; Bevan \& Danbolt, 2000; Omet \& Nobanee, 2001; Huang \& Song, 2002; Antonion et al., 2002, Buferna et al., 2005; Al-Najjar, 2011; Khrawish \& Khraiwesh, 2010) (Note 4). Also, a few researchers have found that this relationship can be negative due to a trade-off between agency costs and expensive debt financing (Note 5). The notion behind this is that even though using more debt is costly, firms with fewer tangible assets use more debt to monitor managerial activity (Jensen \& Meckling, 1976; Titman \& Wessels, 1988; Bhaduri, 2002).

Therefore, based on the above arguments, this study stipulates that there is a relationship between asset structure and the leverage:

$\mathrm{H}_{1 \mathrm{a}}$ : Asset Structure will be negatively related to Short-term debt.

$\mathrm{H}_{1 \mathrm{~b}}$ : Asset Structure will be positively related to Long-term debt.

$\mathrm{H}_{1 \mathrm{c}}$ : Asset Structure will be positively related to Total debt.

Several studies indicate to a positive relationship between size and leverage, suggesting that as firms grow, they tend to take on more leverage, but also become more diversified in their projects, ultimately reducing the probability of failure and favouring the trade-off theory (Smith \& Warner, 1979; Ang et al., 1982; Bradley et al., 1984; Long \& Malitz, 1985; Pettit \& Singer, 1985; Harris \& Raviv, 1991; Rajan \& Zingales, 1995; Al-Siddiq, 2002; Bhaduri, 2002; Al-Najjar, 2011). A positive relationship between size and leverage was also suggested by Gleason et al. (2000) in the notion that firm size is positively related to firm performance. This would suggest that larger firms are more diversified (Titman \& Wessels, 1988), and have easier access to capital markets and favourable interest rates (Ferri \& Jones, 1979).

Size also has a tendency to be negative when short-term liabilities are used to represent leverage and positive when long-term liabilities are used (Bevan \& Danbolt, 2002) They claimed that more profitable firms should hold less debt because of the high level of internal funding this provides. Furthermore, Frielinghaus et al. (2005) maintained that companies prefer more debt in early stages, while opting for internal sources as the life stages advance, concluding that this favors the pecking order theory. Accordingly, the hypothesis states that:

$\mathrm{H}_{2 \mathrm{a}}$ : Firm Size will be negatively related to Short-term Debt.

$\mathrm{H}_{2 \mathrm{~b}}$ : Firm Size will be positively related to Long-term Debt.

$\mathrm{H}_{2 \mathrm{c}}$ : Firm Size will be positively related to Total Debt. 
Based on both the pecking-order and trade-off theories, a firm's volatility of earnings (operating risk) increases probability of default because debt holders consider a firm's future earnings as protection for debt (Mehran, 1992). Therefore, high risk firms may have a negative impact on firm leverage levels. Aligned with that, Subadar et al. (2010) find a significant negative relationship between Mauritius financial firms' risk and leverage levels. This is consistent with McConnell and Pettit (1984), who explain that high risk firms have higher probability of bankruptcy because they tend to have less gearing. In contrast, agency cost theory predicts a positive relationship between risk and leverage, because risk intensifies a negative impact on asymmetric information (Schoubben, 2004). However, limited empirical studies find a significant positive relationship between firm risk and leverage ratio (Jordan et al., 1998; Michaelas et al., 1999). This may be due to distressed firms preferring to borrow more external financing to overcome bankruptcy. In the case of Jordanian firms, the hypotheses state that;

$\mathrm{H}_{3 \mathrm{a}}$ : Firm Risk will be positively related to Short-term Debt.

$\mathrm{H}_{3 \mathrm{~b}}$ : Firm Risk will be positively related to Long-term Debt.

$\mathrm{H}_{3 \mathrm{c}}$ : Firm Risk will be positively related to Total Debt.

Furthermore, taxpaying firms would be expected to substitute debt for equity, at least up to the point where the probability of financial distress starts to be important. However, firms in practice do not follow this policy. Generally speaking, smaller organizations derive less benefit from the tax shelter of deductible corporate interest (McConnell \& Pettit, 1984; Ang, 1991, 1992); and the greater the potential bankruptcy for small business implies that smaller firms should use less debt than their larger counterparts (McConnell and Pettit, 1984 and Pettit and Singer, 1985). Among the literature on non-debt tax shields, Chiarella et al. (1991), Michaelas et al. (1998), Hall et al. (2000), Mira (2001) and Gajdke (2002) find support for a positive relationship of non-debt tax shields to short-term debt, a negative relationship with long-term debt and total debt. Accordingly, and following previous studies, it is hypothesized here that the greater the non-debt tax shields in Jordanian firms and therefore the increased need for investment, the greater the amount borrowed.

$\mathrm{H}_{4 \mathrm{a}}$ : Non-Debt Tax Shield will be positively related to Short-term Debt.

$\mathrm{H}_{4 \mathrm{~b}}$ : Non-Debt Tax Shield will be negatively related to Long-term Debt.

$\mathrm{H}_{4 \mathrm{c}}$ : Non-Debt Tax Shield will be negatively related to Total Debt.

Given the information asymmetries which arises from the higher costs associated with external capital, firms that are profitable would have a preference for internal financing rather than using debt. Myers (1984) and Myers and Majluf (1984) among others have suggested that a hierarchy does exist in the financing of companies. Therefore, the relationship between profitability and leverage should be negative. Empirical evidences from previous studies show a negative relationship between debt and profitability which is consistent with Myer's (1984) Pecking Order Theory (Wijst \& Thurik, 1993; Chittenden et al., 1996; Jordan et al., 1998; Michaelas et al., 1999). Simply put, a firm which can generate more earnings will borrow less, ceteris paribus (Adedeji, 1998). However, there are a few studies which have supported the positive relationship between leverage and profitability and include Chang (1987), Friend and Hasbrouck (1988), Titman and Wessel (1988), Rajan and Zingales (1995), Wald (1999), Booth et al. (2001), and Fama and French (2002) and Chen and Strange (2005). Jensen (1986) argues that the relationship between leverage and profitability depends on the effectiveness of the market for corporate control. If the market for corporate control is effective, managers of profitable firms are forced to pay out cash by leveraging up; on the supply side, lenders are also more willing to lend to profitable firms. Therefore, the relationship between leverage and profitability can be positive. The hypotheses proposed for this study are:

$\mathrm{H}_{5 \mathrm{a}}$ : Profitability will be negatively related to Short-Term Debt.

$\mathrm{H}_{5 \mathrm{~b}}$ : Profitability will be negatively related to Long-term debt.

$\mathrm{H}_{5 \mathrm{c}}$ : Profitability will be negatively related to Total debt.

According to the pecking order theory, firms have a preference for internal finance over external finance; and that the availability of internal funds are captured by liquidity. Weston et al. (2005) showed that the liquidity of a firm's equity affects the ease with which a company can raise external capital through stock offerings. Furthermore, Graham and Harvey (2001), Baker and Stein (2004), and Lipson and Mortal (2006) suggest that a stock's or asset's liquidity will alter a firm's capital structure because managers have an incentive to raise money by issuing equity rather than debt when a stock's liquidity is high, with Graham and Harvey (2001) adding that market timing may also play an important role.

Therefore, if the pecking order theory holds, liquidity should be negatively correlated to a firm's capital structure. The majority of empirical evidence favours the view that profitability and liquidity are negatively related to debt 
ratios (Titman \& Wesssels, 1988; Friend \& Lang, 1988; Rajan \& Zingales, 1995; Kim et al., 1998; Opler et al., 1999; Campbell \& Jerzemowska, 2001; Bevan \& Danbolt, 2002; Gajdka, 2002; Lipson \& Mortal, 2009; Akdal, 2010). Drever and Hutchinson (2007) and Sarlija and Harc (2012) show indirectly that a negative relationship exists between liquidity and short and long-term debt. Anderson (2002) also finds a negative but non-significant relationship to short-term debt, but a positive relation existing between liquidity and long-term debt.

Concerning the hypothesis developed for liquidity, it predicts that the higher the liquidity is, the less a firm has to rely on external debt, so:

$\mathrm{H}_{6 \mathrm{a}}$ : Liquidity will be negatively related to Short-term debt.

$\mathrm{H}_{6 \mathrm{~b}}$ : Liquidity will be positively related to Long-term debt.

$\mathrm{H}_{6 c}$ : Liquidity will be negatively related to Total debt.

Firms which exhibit growth tend to have more flexibility in their future investments which in turn can cause agency problems to become severe. This can be due to the fact that variations due to growth, specifically the larger variations, are often interpreted as greater risk. Thus, a firm is likely to employ less debt in its capital structure (Havokimian et al., 2001; Ozkan, 2001; Daskalakis \& Psillaki, 2008). Myers (1977) suggests that firms with higher growth tend to use more short-term debt and less long-term debt in order to reduce agency costs. This negative relationship between expected growth rate and long-term debt was also highlighted by Titman and Wessels (1988).

Nevertheless, there is also an indication that growth increases firm performance (Zeitun \& Tian, 2007), and adds value to firms, thereby reducing the likelihood of bankruptcy and ultimately increasing the capacity to take on long-term debt (Bhaduri, 2002; Al-Najjar, 2011). Bhaduri (2002) affirms that firms tend to borrow more in their growth in order to support their planned capital expenditure. Cassar and Holmes (2003), and Voulgaris et al (2004) also show support for the negative relationship between leverage and growth opportunities. In accordance to this, the hypotheses for growth opportunities stipulate that:

$\mathrm{H}_{7 \mathrm{a}}$ : Growth opportunity is positively related to short-term debt.

$\mathrm{H}_{7 \mathrm{~b}}$ : Growth opportunity is negatively related to long-term debt.

$\mathrm{H}_{7 \mathrm{c}}$ : Growth opportunity is positively related to total debt.

Furthermore, firms possessing an optimal capital structure and ownership structure serve as a toll to alleviate agency costs. This is due to the fact that investors have a tendency to collect and explain information related to their investments' performance. Therefore, a negative relationship is expected between ownership structure and capital structure (Jensen \& Meckling, 1976; Jensen, 1986; Chaganti \& Damanpour, 1991; Bathala et al., 1994; Grier \& Zychowicz, 1994; Al-Najjar, 2011).

The argument that there is a positive relationship between capital structure and ownership structure was highlighted by Leland and Pyle (1977), Berger et al. (1997) and Chen and Steiner (1999), indicating that investors prefer firms with higher debt levels. Firms tend to rely more on leverage to as they grow to finance their capital structure were increased leverage enhances shareholder wealth by achieving higher tax shields. Holz (2002) suggests that firms tend to finance their investments by borrowing in order to maximize performance.

According to Al-Najjar (2011), institutional investors in Jordan are seen as an index for insider ownership as they are the main owners and can control the firm. As much as leverage may increase value for these firms, debt imposes restrictive covenants and risks at various levels. According to tax based theories, taxpaying firms would be expected to substitute debt for equity, at least up to the point where the probability of financial distress starts to be important. Heavy use of long-term debt subjects firms to disciplinary restrictions which may prevent them from distributing earnings because of their focus on the burden of debt repayment. Furthermore, short-term debt may also expose these firms to the risk of refinancing (Zeitun \& Tian, 2007). Therefore, taking into consideration the arguments above, the hypotheses for ownership structure state that:

$\mathrm{H}_{8 \mathrm{a}}:$ Ownership structure is positively related to short-term debt.

$\mathrm{H}_{8 \mathrm{~b}}$ : Ownership structure is negatively related to long-term debt.

$\mathrm{H}_{8 \mathrm{c}}$ : Ownership structure is negatively related to total debt.

Furthermore, the board of directors who are responsible for managing a firm and its operations play a vital role in capital structure decisions. Evidence of the significance and relationship between board size and capital structure have been highlighted by a few studies (Pfeffer \& Salancick, 1978). Berger et al. (1997) and Abor (2007) for instance provide evidence of a negative relationship arguing that firms with larger board of directors 
generally have lower debt levels. On the other hand, Jensen (1986), Wen et al. (2002), Anderson et al. (2003) and Coles et al. (2008) indicated a positive relationship on the notion that firms using higher levels of debt enhance firm value and are thought by lenders to be more effectively monitored by a diversified portfolio of experts. In the case of Jordanian firms, the hypotheses regarding board size and debt levels are:

$\mathrm{H}_{9 \mathrm{a}}$ : Board Size is positively related to short-term debt.

$\mathrm{H}_{9 \mathrm{~b}}$ : Board Size is negatively related to long-term debt.

$\mathrm{H}_{9 \mathrm{c}}$ : Board Size structure is negatively related to total debt.

Another variable to consider is $\mathrm{CEO} / \mathrm{Chair}$ duality which can be seen to have a direct impact on the financing decisions of firms. Fama and Jensen (1983) argue that in a firm, decision management and decision control functions should be separate. The presence of $\mathrm{CEO} / \mathrm{Chair}$ duality may signal the absence of separation of decision management and decision control and ultimately leads to agency problems. However, a few studies have shown that duality leadership reduces problems related to separation of ownership and control, reducing information asymmetry and granting firms access to external debt. Therefore, CEO duality companies have high accessibility to external financing (Wellalage \& Locke, 2012). Fosberg (2004) and Arbor (2007) also find that firms with duality in ownership tend to have high debt to equity ratios. Furthermore, Faleye (2004) suggests that the duality is also attributable to small board size firms. Accordingly, it is hypothesized that firms in Jordan with small board size to have a positive relationship between CEO/duality and short-term debt whereas a negative relationship with long-term debt. The hypotheses therefore state that:

$\mathrm{H}_{10 a}$ : CEO/Duality is positively related to short-term debt.

$\mathrm{H}_{10 \mathrm{~b}}$ : CEO/Duality is negatively related to long-term debt.

$\mathrm{H}_{10 \mathrm{c}}:$ :CEO/Duality structure is negatively related to total debt.

Finally, non-executives also play a vital role in firm strategic financing decisions controlling the activities of the board of directors in general. The importance of non-executive directors as a supervisory instrument has been emphasized in recent decades for corporate board independence (Higgs Report, 2003). Their supervisory and balancing roles are pivotal in enhancing recognition by external stake holders thereby reducing both agency conflict and uncertainty about a firm and enhancing the raising of external funds (Pfeffer \& Salancick, 1978). A few studies have found a positive relationship between non-executive directors and debt levels (Jensen, 1986; Berger et al., 1997; Abor, 2007). However, there is a plausible reason why such a relationship can be negative (Wen et al., 2002), suggesting that firms with higher representation of non-executive directors are forced to seek lower financial leverage with a higher market value of equity (Hasan \& Butt, 2009). In the case of Jordanian firms, the association of non-executive directors with short-term debt is expected to be positive and with long-term debt to be negative. Therefore, the hypotheses stipulate that:

$\mathrm{H}_{11 \mathrm{a}}$ : Non-executive structure is positively related to short-term debt.

$\mathrm{H}_{11 \mathrm{~b}}$ : Non-executive structure is negatively related to long-term debt.

$\mathrm{H}_{11 \mathrm{c}}$ : Non-executive structure is negatively related to total debt.

\section{Methodology}

\subsection{Data Nature and Scope}

The sample for the study consisted of 344 observations obtained from the Amman Stock Exchange (ASE). These observations pertain to industrial companies listed on the exchange covering all sectors according to the ASE's classification. The study period for which the observations were attained ranged from 2006 until 2011.

\subsection{Measurement of Variables}

In each of the empirical hypotheses formulated in the previous section, an economic or financial attributes of the firm was taken into account with a question in mind, namely of how to measure these attributes. Capital structure theory does not specify clearly this issue, which has taken some researchers like Titman and Wessels (1988), or Harris and Raviv (1991) to conclude that the choice of appropriate dependent and explanatory variables is potentially controversial. Nonetheless, previous empirical work can help us to define objectively the proxy variables needed to undertake this study.

The sample for the study consisted of 344 observations obtained from the Amman Stock Exchange (ASE). These observations pertain to industrial companies listed on the exchange covering the industrial sector according to the ASE's classification. The study period for which the observations were attained ranged from 2006 until 2011. The variables used in this study as an indicator of a firm's capital structure are the Total Debt Ratio $\left(T D_{i . t}\right)$, 
Short-Term Debt $\left(S T D_{i, t}\right)$, and Long-Term Debt $\left(L T D_{i, t}\right)$. Even though a few studies argued against the use of total debt (Note 6), for the simple reason of comparison to past studies, this measure is included as well. Following previous capital structure literature, the dependent and independent variables were measured as follows (Table 1).

Table 1. Measurement of dependent and independent variables

\begin{tabular}{ll}
\hline Dependent Variables & Measurement \\
\hline Total Debt $\left(\mathrm{TD}_{\mathrm{i}, \mathrm{t}}\right)$ & Total Liabilities divided by Total Assets \\
Short-term Debt $\left(\mathrm{STD}_{\mathrm{i}, \mathrm{t}}\right)$ & Short-term Liabilities divided by Total Assets \\
Long-term Debt $\left(\mathrm{LTD}_{\mathrm{i}, \mathrm{t}}\right)$ & Long-term Liabilities divided by Total Assets \\
\hline Independent Variables $($ Note 8$)$ & \\
\hline Asset Structure $\left(\mathrm{AST}_{\mathrm{i}, \mathrm{t}}\right)$ & Tangible Fixed Assets divided by Total Assets \\
Size $\left(\right.$ SIZE $\left._{i, t}\right)$ & Absolute value of Total Assets \\
Firm Risk $\left(\mathrm{RISK}_{\mathrm{i}, \mathrm{t}}\right)$ & Standard deviation of the annual earnings, scaled by the average value of the total assets over time. \\
Non-Debt Tax shields $\left(\mathrm{NDTS}_{\mathrm{i}, \mathrm{t}}\right)$ & Depreciation divided by Total Assets \\
Profitability $\left(\mathrm{PROF}_{\mathrm{i}, \mathrm{t}}\right)$ & Earnings before Interest and Tax divided by Total Assets \\
Liquidity $\left(\mathrm{LIQ}_{\mathrm{i}, \mathrm{t}}\right)$ & Current Assets - Current Liabilities; divided by Total Assets \\
Growth $\left(\mathrm{GROW}_{\mathrm{i}, \mathrm{t}}\right)$ & Growth on Total Assets \\
Ownership Structure $(\mathrm{OWST}$ & Percentage of shares held by members of board disclosed in annual financial reports \\
Board Size $\left(\mathrm{BOARD}_{\mathrm{i}, \mathrm{t}}\right)$ & Logarithm of number of board members \\
CEO/Duality $\left(\mathrm{CEO}_{\mathrm{i}, \mathrm{t}}\right)$ & Dummy Variable, 1 if CEO is chairman; otherwise it is taken as 0. \\
Non-executive Structure $\left(\mathrm{NONEX}_{\mathrm{i}, \mathrm{t}}\right)$ & Number of non-executive directors divided by total number of directors \\
\hline
\end{tabular}

\subsection{The Model}

Modeling for the Jordanian firms, according to the variables described in the previous section, the regression models used follow those of Al-Najjar (2011) and take the following form:

$$
\begin{array}{lc}
\boldsymbol{D}_{\boldsymbol{i t}}=\beta_{0}+\beta_{i} X_{i, t}+\varepsilon_{i, t} & \text { (Pooled Model) } \\
\boldsymbol{D}_{\boldsymbol{i t}}=\beta_{i}+\beta_{i} X_{i, t}+\varepsilon_{i, t} & \text { (Fixed Effect Model) } \\
\boldsymbol{D}_{\boldsymbol{i t}}=\beta_{0}+\beta_{i} X_{i, t}+\left(\varepsilon_{i, t}+\mu_{i}\right) & \text { (Random Effects Model) }
\end{array}
$$

Where $i$ is the number of observations, $t$ is the number of explanatory variables, $\beta_{0}$ is constant, while $\beta_{\mathrm{i}}$ are the row vector of slope regression coefficients, and $X_{i, t}$ are the column vector of financial variables of firm $i$ at time $t$. $\mathrm{D}_{\mathrm{i}, \mathrm{t}}$ represent the debt to asset ratios developed for this study.

When replacing the variables chosen in this study to represent leverage and the explanatory factors for the capital structure of the Jordanian firms, 3 regression models are obtained as follows:

$$
\begin{aligned}
& \boldsymbol{S T D}_{i, t}=\beta_{0}+\beta_{1} A S T_{i, t}+\beta_{2} \operatorname{SIZE}_{i, t}+\beta_{3} \text { RISK }_{i, t}+\beta_{4} N D T S_{i, t}+\beta_{5} \text { PROF }_{i, t}+\beta_{6} L_{I} Q_{i, t}+\beta_{7} \text { GROW }_{i, t}+\beta_{8} O W S T_{i, t}+ \\
& \beta_{9} B O A R D_{i, t}+\beta_{10} C E O_{i, t}+\beta_{11} N O N E X_{i, t}+\varepsilon_{i, t} \\
& \boldsymbol{L T D}_{i, t}=\beta_{0}+\beta_{1} A S T_{i, t}+\beta_{2} S_{I Z E_{i, t}}+\beta_{3} \operatorname{RISK}_{i, t}+\beta_{4} N D T S_{i, t}+\beta_{5} P R O F_{i, t}+\beta_{6} L I Q_{i, t}+\beta_{7} \text { GROW }_{i, t}+\beta_{8} O W S T_{i, t}+ \\
& \beta_{9} B_{1 A R D_{i, t}}+\beta_{10} C E O_{i, t}+\beta_{11} N O N E X_{i, t}+\varepsilon_{i, t} \\
& \boldsymbol{T D}_{i, t}=\beta_{0}+\beta_{1} A S T_{i, t}+\beta_{2} \operatorname{SIZE}_{i, t}+\beta_{3} \text { RISK }_{i, t}+\beta_{4} N D T S_{i, t}+\beta_{5} \text { PROF }_{i, t}+\beta_{6} L_{I} Q_{i, t}+\beta_{7} \text { GROW }_{i, t}+\beta_{8} O W S T_{i, t}+ \\
& \beta_{9} \text { BOARD }_{i, t}+\beta_{10} \text { CEO }_{i, t}+\beta_{I I} N O N E X_{i, t}+\varepsilon_{i, t}
\end{aligned}
$$

Where $\mathrm{STD}_{\mathrm{i}, \mathrm{t}} \mathrm{LTD}_{\mathrm{i}, \mathrm{t}}$, and $\mathrm{TD}_{\mathrm{i}, \mathrm{t}}$ are the variables to be explained (short-term debt, long-term debt, and total debt); $\mathrm{AST}_{\mathrm{i}, \mathrm{t}}$ is asset structure (given by tangible fixed assets over total assets ratio); $\mathrm{SIZE}_{\mathrm{i}, \mathrm{t}}$ denotes size variable; RISK $_{i, t}$ refers to firm risk level; GROW ${ }_{i, t}$ is the growth opportunity variable; NDTS $\mathrm{i}_{\mathrm{i}, \mathrm{t}}$ is used to represent non-debt tax shields in the regression; $\mathrm{PROF}_{\mathrm{i}, \mathrm{t}}$ denotes is the profitability variable; $\mathrm{LIQ}_{\mathrm{i}, \mathrm{t}}$ is the variable of Liquidity (represented by net working capital); $\mathrm{OWST}_{\mathrm{i}, \mathrm{t}}$ is used to represent ownership structure (or Institutional Ownership); BOARD $\mathrm{i}_{\mathrm{i}, \mathrm{t}}$ denotes the variable for Board Size; $\mathrm{CEO}_{\mathrm{i}, \mathrm{t}}$ represents $\mathrm{CEO} /$ Duality; and $\mathrm{NONEX}_{\mathrm{i}, \mathrm{t}}$ refers to the final variable of Non-executive Structure. 
This study developed regression models in a panel data framework to measure the dependence of capital structure on the variables chosen for this study including corporate governance variables. The panel data analysis helps to explore cross-sectional and time series data simultaneously. The most recent version of the STATA statistical program was used to run pooled, random and fixed effect regressions on the models developed in equations 4 to 6 . When using Fixed Effect it is assumed that certain factors within the firm may impact or bias the predictor or outcome variables and that those time-invariant characteristics are unique to the firm and should not be correlated with other individual characteristics. Therefore the Fixed Effect model is applied because of the need to control for such factors (Al-Najjar, 2011).

In addition, an $F$-test is also performed to determine the significance of the models employed. Furthermore, descriptive analysis and correlation matrices were derived to determine any significant inter-correlation between the variables of the study. This is expected to aid in providing additional support to the results of the regression analysis in explaining the case of the Jordanian firms being examined.

\section{Empirical Results and Analysis}

Examining the determining factors that influence the financial behaviour of industrial firms in Jordan, this study analyses not only the effects of the chosen determinants on total leverage, but also on varying debt maturities, i.e. short and long-term debt as well.

\subsection{Descriptive Statistics}

The descriptive statistics highlights some important indicators which can assist in shedding light on the results of the study. Table 2 examines the average leverage ratios across Jordan, revealing that short-term debt was the predominant type of financing used by Jordanian firms over the period of the study. This greater use of short-term debt indicates that firms temporary commitments to creditors rather than long-term restrictions. Kharawish (2008) suggests that Jordanian industrial companies rely heavily on equity financing, up to $70 \%$, with the remaining being dependent on short-term debt. Buferna et al. (2005) find that Libyan firms were also extremely financed, preferring short-term debt sources. Furthermore, several studies including Bevan and Danbolt (2002), Antoniou et al. (2002), and Cassar and Holmes (2003) have highlighted the existence of a positive relationship between profitability and debt financing. The statistics reveal that Jordanian firms have relatively low profitability which could explain their high reliance on external debt, especially of the short-term nature. Also, the growing firms tend to rely on their internal funds while larger firms will tend to have higher leverage ratios. The following section of regression results may lend hand to support these results and provide more conclusive and concrete explanations to the determinants of capital structure in these firms.

Table 2. Sample summary statistics for 344 observations

\begin{tabular}{lllll}
\hline Variables $^{\mathrm{a}}$ & Mean & Std. Deviation & Minimum & Maximum \\
\hline TD & 0.3311993 & 0.1960132 & 0.0148 & 1.0814 \\
STD & 0.2706222 & 0.1616646 & 0.009 & 0.8356 \\
LTD & 0.0605778 & 0.1103144 & 0 & 0.7401 \\
AST & 0.3878059 & 0.1866384 & 0.007 & 0.8815 \\
SIZE & 16.53404 & 1.323323 & 13.6621 & 20.9248 \\
NDTS & 0.0301989 & 0.0213427 & 0 & 0.1179 \\
PROF & -0.0017704 & 0.1152947 & -0.6001 & 0.433 \\
LIQ & 0.2328722 & 0.2248772 & -0.5358 & 1.15 \\
RISK & 0.0053452 & 0.0197106 & 0 & 0.2829 \\
GROW & 0.0189307 & 0.1795115 & -0.5375 & 1.1085 \\
NONEX & 0.2220741 & 0.2749332 & 0 & 1 \\
OWST & 0.1666667 & 0.0985047 & 0 & 1 \\
CEO & 0.2535963 & 0.2167697 & 0 & 0.95 \\
BOARD & 0.9441481 & 0.0985047 & 0.6 & 1.15 \\
\hline
\end{tabular}

Note. ${ }^{\text {a TD }}=$ Total Debt; STD = Short-term Debt; LTD = Long-term Debt; AST = Asset Structure; SIZE = Firm Size; NDTS = Non-debt Tax Shields; PROF $=$ Profitability; LIQ $=$ Liquidity; RISK $=$ Firm Risk level; GROW $=$ Firm Growth; NONEX $=$ Non-executives; OWST $=$ Ownership Structure; $\mathrm{CEO}=. \mathrm{CEO} /$ Duality; BOARD $=$ Board Size. 


\subsection{Regression}

Examining the regression analysis of the three models employed reveals mixed results. First, in the case of the Total Debt model (Table 3), the results from the pooled model show that Jordanian firms were significantly influenced by all factors except Non-debt Tax shields and Risk and exhibited an R-Square value of 0.5947. Under the fixed and random effect models, the most significant predictors of capital structure were Asset Structure, profitability, liquidity, firm growth with corporate governance variables showing little or no significance. The R-squares for the fixed and random effect models were 0.5254 and 0.5056 respectively.

Furthermore, examining Table 4 for Short-term Debt, the results for the pooled model reveal that all of the chosen variables were significantly influential except for firm size and firm risk with an R-square of 0.5265 . On the other hand, the variables most significantly affecting capital structure in the fixed and random effect models were asset structure, liquidity, and firm growth. The variable of firm size was significant only for the fixed effect model while board size was significant for the random effect model. Both of the fixed and random effect models outperformed those for the Total Debt model with R-squares of 0.8164 and 0.8075 respectively.

Finally, regarding the Long-term Model examined (Table 5), the pooled model revealed that out of the eleven variables chosen, only five variables showed significance, namely asset structure, firm size, liquidity, $\mathrm{CEO} /$ Duality, and non-executive structure. Moreover, the pooled model had a much weaker explanatory power with the R-Square of 0.2770 . Concerning the fixed and random effect models, the explanatory power were also weaker than the other debt models developed, with R-squares at 0.2163 for the fixed and 0.1754 for the random effects model. The majority of the variables were found not to have any significance in explaining the capital structure of the Jordanian firms examined, except for asset structure and liquidity; and profitability for the fixed effects model.

Table 3. Panel data regression results for of Jordanian firms for 344 observations from 2006-2011

\begin{tabular}{|c|c|c|c|}
\hline \multicolumn{4}{|c|}{ Dependent Variable: Total Debt } \\
\hline Independent Variable & Pooled Model & Fixed Effects Model & Random Effects Model \\
\hline \multirow[t]{2}{*}{ Constant } & 0.6288874 & & 0.6371752 \\
\hline & $(4.32)^{* * *}$ & & $(2.90)^{* * *}$ \\
\hline \multirow[t]{2}{*}{ AST } & -0.1121566 & -.2527739 & -0.1819192 \\
\hline & $(-2.08)^{* *}$ & $(-3.29)^{* * *}$ & $(-2.92)^{* * *}$ \\
\hline \multirow[t]{2}{*}{ SIZE } & 0.0194134 & 0.0142491 & 0.0065045 \\
\hline & $(2.44)^{* *}$ & $(0.57)$ & $(0.51)$ \\
\hline \multirow[t]{2}{*}{ NDTS } & -0.2541165 & -0.0738988 & -0.159701 \\
\hline & $(-0.57)$ & $(-0.21)$ & $(-0.45)$ \\
\hline \multirow[t]{2}{*}{ PROF } & -0.561359 & -0.1167035 & -0.1761621 \\
\hline & $(-5.17)^{* * *}$ & $(-1.76)^{*}$ & $(-2.65)^{* * *}$ \\
\hline \multirow[t]{2}{*}{ LIQ } & -0.4792413 & -0.6110229 & -0.5695496 \\
\hline & $(-11.52)^{* * *}$ & $(-11.61)^{* * *}$ & $(-12.15)^{* * *}$ \\
\hline \multirow[t]{2}{*}{ RISK } & -0.210805 & 0.0913749 & 0.0663529 \\
\hline & $(-0.46)$ & $(0.39)$ & $(0.28)$ \\
\hline \multirow[t]{2}{*}{ GROW } & 0.1718018 & 0.0471601 & 0.0598003 \\
\hline & $(3.28)^{* * *}$ & $(1.77)^{*}$ & $(2.25)^{* *}$ \\
\hline \multirow[t]{2}{*}{ NONEX } & 0.0889715 & -0.0653085 & 0.0095341 \\
\hline & $(2.76)^{* * *}$ & $(-1.69)^{*}$ & $(0.27)$ \\
\hline \multirow[t]{2}{*}{ CEO } & -0.1172509 & 0.0144414 & -0.00295 \\
\hline & $(-5.37)^{* * *}$ & $(0.78)$ & $(-0.16)$ \\
\hline \multirow[t]{2}{*}{ OWST } & -0.1008281 & -0.056729 & -0.0568306 \\
\hline & $(-2.43)^{* * *}$ & $(-1.02)$ & $(-1.16)$ \\
\hline \multirow[t]{2}{*}{ BOARD } & -0.4593198 & -0.0039581 & -0.1970183 \\
\hline & $(-5.31)^{* * *}$ & $(-0.03)$ & $(-1.82)^{*}$ \\
\hline Number of Observations & 344 & 344 & 344 \\
\hline R Square & 0.5947 & 0.5254 & 0.5056 \\
\hline Hausman Test & $14.32 * * *$ & & \\
\hline
\end{tabular}


Table 4. Panel data regression results for of Jordanian firms for 344 observations from 2006-2011

\begin{tabular}{|c|c|c|c|}
\hline \multicolumn{4}{|c|}{ Dependent Variable: Short-term Debt } \\
\hline Independent Variable & Pooled Model & Fixed Effects Model & Random Effects Model \\
\hline \multirow[t]{2}{*}{ Constant } & 0.738633 & & 0.8377614 \\
\hline & $(5.70)^{* * *}$ & & $(4.67)^{* * *}$ \\
\hline \multirow[t]{2}{*}{ AST } & -0.3319243 & -0.6028395 & -0.5417727 \\
\hline & $(-6.89)^{* * *}$ & $(-12.30)^{* * *}$ & $(-11.95)^{* * *}$ \\
\hline \multirow[t]{2}{*}{ SIZE } & 0.0053577 & 0.0339211 & 0.0029185 \\
\hline & $(0.76)$ & $(2.11)^{* *}$ & $(0.28)$ \\
\hline \multirow[t]{2}{*}{ NDTS } & 0.8808247 & -0.0461679 & 0.03305 \\
\hline & $(2.20)^{* *}$ & $(-0.20)$ & $(0.14)$ \\
\hline \multirow[t]{2}{*}{ PROF } & -0.5113609 & -0.0000846 & -0.0587789 \\
\hline & $(-5.28)^{* * *}$ & $(-0.00)$ & $(-1.32)$ \\
\hline \multirow[t]{2}{*}{ LIQ } & -0.4155524 & -0.8905513 & -0.7964078 \\
\hline & $(-11.20)^{* * *}$ & $(-26.52)^{* *}$ & $(-24.03)^{* * *}$ \\
\hline \multirow[t]{2}{*}{ RISK } & -0.5249296 & 0.0032426 & -0.0840763 \\
\hline & $(-1.28)$ & $(0.02)$ & $(-0.53)$ \\
\hline \multirow[t]{2}{*}{ GROW } & 0.1573165 & 0.0507218 & 0.0690887 \\
\hline & $(3.37)^{* * *}$ & $(2.99)^{* * *}$ & $(3.88)^{* * *}$ \\
\hline \multirow[t]{2}{*}{ NONEX } & 0.0490263 & -0.0455518 & -0.0236295 \\
\hline & $(1.71)^{*}$ & $(-1.85)^{*}$ & $(-0.97)$ \\
\hline \multirow[t]{2}{*}{ CEO } & -0.0585697 & 0.0017894 & -0.0013463 \\
\hline & $(-3.01)^{* * *}$ & $(0.15)$ & $(-0.11)$ \\
\hline \multirow[t]{2}{*}{ OWST } & -0.0654256 & 0.015558 & -0.001245 \\
\hline & $(-1.77)^{*}$ & $(0.44)$ & $(-0.04)$ \\
\hline \multirow[t]{2}{*}{ BOARD } & -0.3636223 & -0.1146323 & -0.2270025 \\
\hline & $(-4.72)^{* * *}$ & $(-1.37)$ & $(-2.89)^{* * *}$ \\
\hline Number of Observations & 344 & 344 & 344 \\
\hline R Square & 0.5265 & 0.8164 & 0.8075 \\
\hline Hausman Test & $15.13 * * *$ & & \\
\hline
\end{tabular}


Table 5. Panel data regression results for of Jordanian firms for 344 observations from 2006-2011

\begin{tabular}{|c|c|c|c|}
\hline \multicolumn{4}{|c|}{ Dependent Variable: Long-term Debt } \\
\hline Independent Variable & Pooled Model & Fixed Effects Model & Random Effects Model \\
\hline \multirow[t]{2}{*}{ Constant } & -0.1097123 & & -0.2729753 \\
\hline & $(-1.00)$ & & $(-1.43)$ \\
\hline \multirow[t]{2}{*}{ AST } & 0.2198015 & 0.3502175 & 0.309907 \\
\hline & $(5.41)^{* * *}$ & $(4.88)^{* * *}$ & $(5.55)^{* * *}$ \\
\hline \multirow[t]{2}{*}{ SIZE } & 0.0140529 & -0.0196656 & 0.0083659 \\
\hline & $(2.35)^{* *}$ & $(-0.84)$ & $(0.76)$ \\
\hline \multirow[t]{2}{*}{ NDTS } & -1.135129 & -0.027897 & -0.2688825 \\
\hline & $(-3.37)^{* * *}$ & $(-0.08)$ & $(-0.83)$ \\
\hline \multirow[t]{2}{*}{ PROF } & -0.0499791 & -0.1165946 & -0.0815163 \\
\hline & $(-0.61)$ & $(-1.88)^{*}$ & $(-1.33)$ \\
\hline \multirow[t]{2}{*}{ LIQ } & -0.0636825 & 0.2795873 & 0.1592007 \\
\hline & $(-2.04)^{* *}$ & $(5.68)^{* * *}$ & $(3.76)^{* * *}$ \\
\hline \multirow[t]{2}{*}{ RISK } & 0.3143803 & 0.0883378 & 0.1798108 \\
\hline & $(0.91)$ & $(0.40)$ & $(0.81)$ \\
\hline \multirow[t]{2}{*}{ GROW } & 0.0144952 & -0.0035564 & -0.0168926 \\
\hline & $(0.37)$ & $(-0.14)$ & $(-0.69)$ \\
\hline \multirow[t]{2}{*}{ NONEX } & 0.0399392 & -0.0197643 & 0.0243867 \\
\hline & $(1.65)^{*}$ & $(-0.55)$ & $(0.78)$ \\
\hline \multirow[t]{2}{*}{ CEO } & -0.0586926 & 0.0126449 & -0.0011601 \\
\hline & $(-3.58) * * *$ & $(0.73)$ & $(-0.07)$ \\
\hline \multirow[t]{2}{*}{ OWST } & -0.0354022 & -0.0412122 & -0.0607798 \\
\hline & $(-1.13)$ & $(-0.79)$ & $(-1.38)$ \\
\hline \multirow[t]{2}{*}{ BOARD } & -0.0956888 & 0.1108191 & 0.0656655 \\
\hline & $(-1.47)$ & $(0.91)$ & $(0.68)$ \\
\hline Number of Observations & 344 & 344 & 344 \\
\hline R Square & 0.2770 & 0.2163 & 0.1754 \\
\hline Hausman Test & $14.34 * * *$ & & \\
\hline
\end{tabular}

\section{Discussion}

This study examined firms from the Jordanian industrial sector in order to empirically test the determinants of capital structure. The hypotheses proposed tested the influence of control variables namely Asset Structure, Firm Size, Non-debt tax shield, Profitability, Liquidity, Firm Growth, and Firm Risk; and also included some corporate governance variables which were proposed by previous studies specifically Non-executive ownership, CEO/Duality, Ownership Structure, and Board Size on financial leverage as a total as well as on short and long-term debt. The results from the pooled and panel results revealed mixed results, most of which indicated to the hypothesis developed and with varying levels of significance.

For asset structure, almost all of the results obtained follow the outcomes expected in the relationship between asset tangibility and leverage of its varying maturities. Examining the data found from the three models proposed revealed that Jordanian firms generally relied more on short-term debt than they did on long-term debt, which may also lend support the negative outcome for total debt. The inverse association found between total and short-term debt and tangible assets can be an indication of the notion that these firms tend to match their duration of assets and liabilities. A few studies have documented such a relationship in the context of small to medium sized firms (Note 7). In addition, such a negative association can also be due to a trade-off between agency costs and expensive debt financing (Jensen \& Meckling, 1976; Grossman \& Hart, 1982; Titman \& Wessels, 1988; Bhaduri, 2002). In regards to Long-term debt, the results are consistent with the majority of literature which confirm that when tangibility of a firm increases, then so does Long-term debt (Harris \& Raviv, 1991; Cassar \& Holmes, 2003; Bevan \& Danbolt, 2000; Omet \& Nobanee, 2001; Huang \& Song, 2002; Antonion et al., 2002, Buferna et al., 2005; Al-Najjar, 2011; Khrawish \& Khraiwesh, 2010).

In terms of firm size, the findings reveal that all of the results were consistent with the prediction made in 
regards to the association with the leverage measures. The results indicate that as these firms grow in size, they tend to take on more debt in the capital structure in favour of the trade-off theory (Ang et al., 1982; Harris \& Raviv, 1991; Al Sadeek, 2002; Al-Najjar, 2011), especially that of short-term nature, which also can be indicative of a positive relationship to firm performance (Gleason, 2000). Furthermore, these results may also suggest that these firms prefer more debt in early stages while opting for internal sources in later stages of growth (Frielinghaus et al., 2005).

Firms which generally exhibit growths tend to face a greater variation or flexibility which is indicative of greater risk and agency problems. Therefore, to avoid such potential problems, these firms are relying on short-term debt as they grow and try to avoid debt of long-term nature to sidestep severe agency problems. The use of short-term debt by these firms seems to add value in light of their growth and reduces the likelihood of bankruptcy (Myers, 1977; Zeitun \& Tian, 2007; Bhaduri; 2002; Al-Najjar, 2011). The results further revealed a positive association with long-term debt which may further suggest that as firms grow their potential to take on long-term debt in spite of its draw backs, also increases. However, this result is contradictory to previous research findings which suggest a negative association with long-term debt (See for example Havokimian et al., 2001; Ozkan, 2001).

The results also reveal a negative relationship between firm risk and leverage which is in support of both the pecking order theory and trade-off theory. Because lenders consider a firm's future earnings as protection for debt (Mehran, 1992), risky firms have a negative impact on debt. The result finds support from McConnell and Petittit, (1984) and Subadar et al. (2010) who also reveal a negative association with leverage. However, the positive relationship found for Long-term debt can be predicted by the agency cost theory, suggesting that risk intensifies a negative impact on asymmetric information (Schoubben, 2004). Even though these firms are not relying on long-term debt in their capital structure, their heavy use of short-term debt can over time increase the level of risk for these firms.

To this matter, the reliance of these firms on short-term debt in their capital structure may explain the positive association with Non-debt tax shields. Generally, smaller firms should be using less debt because they derive less benefit from the tax shelter of debt especially long-term debt (McConnell \& Pettit, 1984; Ang, 1991, 1992). It seems that Jordanian firms take advantage of the tax shelter of corporate deductible interest which arises from short-term debt, which can in turn reflect positively on their profitability. The positive association finds support among previous literature among them those of Chiarella et al. (1991), Michaelas et al. (1998), Hall et al. (2000), Mira (2001) and Gajdke (2002).

In the case of profitability and liquidity, the results of the study coincides with previous finding that more profitable and liquid firms generally take on less debt in their capital structure; and could suggest the existence of hierarchy in financing in these companies (Myers, 1984). Among many of the previous literatures, Wijst and Thurik, (1993); Chittenden et al. (1996); Adedeji, (1998); Jordan et al. (1998); Michaelas et al. (1999); Gajdka (2002); Lipson and Mortal, (2009); Akdal, (2010) support the negative relationship between profitability and liquidity, and leverage. Drever and Hutchinson (2007) and Sarlija and Harc (2012) further support the results of this study by showing indirectly that a negative relationship exists between liquidity and short and long-term debt. Anderson (2002) also reaffirms a negative but non-significant relationship to short-term debt, but a positive relation between liquidity and long-term debt.

Also, concerning the corporate governance variables, the positive signs in the results reveal that non-executives do seem to play a vital role in the financing decisions of these firms thereby enhancing their recognition by lenders. According to Pfeffer and Salancick, (1978), this supervisory and balancing role reduces agency conflict and uncertainty, and therefore may explain why these firms rely on short-term financing. Jensen, (1986); Berger et al. (1997); and Abor (2007) support the positive relationship between non-executive ownership and leverage.

In addition, the negative associations of Ownership structure, CEO/Duality and Board Size with leverage may shed some light on the structure of these firms in Jordan. First, these firms generally exhibit duality and therefore its debt to equity ratios should be higher. According to Faleye (2004), duality is also attributable to small board size and along with higher non-executive ownership may allow these firms better access to external debt (Fosberg, 2004; Abor, 2007; Wellage \& Locke, 2012). Therefore, these firms with their board size and duality composition benefit better from the use of short-term debt due to the possible reduced risk of refinancing. Moreover, the institutional investors are seen as the index for insider ownership in Jordan (Al-Najjar, 2011) and the heavy use of long-term debt may impose restrictions and burdens on debt repayment which can lend support the negative association of ownership structure with leverage.

Regarding the Random and Fixed Effect models utilized, the majority of the results found do confirm the hypotheses developed. Nevertheless, the Fixed Effect model was able to significantly control certain 
characteristics and thereby was a better model in confirming some of the hypotheses developed which the random model could not.

First, the fixed effect model revealed a positive relationship between liquidity and Long-term debt suggesting that firms with higher liquidity tend to rely more on long-term debt. This may be explained by the fact that the liquidity of a firm's equity may ease a firm's access to external financing and be able to mitigate problems associated with potential bankruptcy. The majority of the literature supports the notion of a negative relationship; however, Anderson (2002) does find a positive relationship between liquidity and long-term debt.

Second, the model also finds that firm risk is positively related to Short-term debt and Total debt. The firms in the study did rely more on short-term as a proportion of the total and can explain why risk levels are higher for these firms. According to Schoubben, (2004), this may be due to the fact that risk intensifies the negative impact on asymmetric information and why distressed firms prefer to borrow more to overcome bankruptcy (Jordan et al., 1998; Michaelas et al., 1999).

Also the analysis revealed a significant negative relationship between firm growth and long-term debt suggesting that as firm size grows, the firms depend less on long-term debt which confirms the hypothesis and is supported by previous studies. Myers, (1977) noted that firms with higher growth tend to use more short-term and less long-term debt to reduce agency costs (Titman \& Wessels, 1988). More recently, Havokimian et al., (2001); Ozkan (2001); and Daskalakis and Psillaki (2008) provide evidence of a negative association of firm growth with leverage.

Furthermore, the model reveals a negative sign for the association of non-executive ownership and long-term debt. In this case, a plausible explanation may be that as the representation of non-executive directors increases, the firms are forced to seek lower financial leverage with higher market value of equity (Wen et al., 2002; Hasan $\&$ Butt, 2009). Finally, the fixed effect model confirms the hypothesis of a positive relationship between $\mathrm{CEO} /$ Duality and short-term debt. With small board size and duality in ownership, these firms are more likely to prefer the use of short-term debt because of the nature of their organizational structure and the benefits gained from better access to external financing and the reduced risk of agency problems.

The results of the study from the three models were mixed. The majority of the hypotheses developed were confirmed by the results of the pooled model and held the highest number of significant values. Even though some of the signs did not confirm the respective hypothesis, the fixed-effect model did enhance some of the predictors to add value to the explanation of the nature of the capital structure decisions faced by the Jordanian firm examined.

\section{Conclusions}

The empirical evidence from this study suggests that like in many of the previous studies asset structure, firm size, firm profitability and liquidity were important influences upon the financing decisions of Jordanian firms. The inclusion of corporate governance factors revealed that they also played a vital role in the capital structure choices of these firms.

Jordanian firms most notably tend to favour leverage of short-term maturity to finance their operations as a proportion of total debt. Factors such as asset structure, firm size, firm growth and firm risk tend to favour the trade-off between agency costs and expensive debt financing. The use of short-term debt rather than internal financing seems to add value to these firms as they grow, especially in the early stages of development, and seem to derive more benefits from the tax shelter this type of debt provides to them. This action as noted in previous literature may increase risk inherent in these firms and intensifies the negative impact on asymmetric information.

Generally more profitable and liquid firms would tend to use less debt in their capital structure. However, Jordanian firms are generally not as profitable and liquid as may seem, or sufficiently so to manage the restrictions and burdens of repayment which accompany long-term debts. Therefore, these firms turn to short-term leverage in an attempt to match the duration of their assets and liabilities and to avoid potentially heavier penalties.

Finally, corporate governance in these firms seem to play as a vital role in the capital structure decisions as the more common factors do. Given the internal nature of these firms in terms size of the board which generally is small and its duality composition and a higher non-executive representation provides better access to external financing with higher market value to equity, in this case short-term debt. The nature of this supervisory and balancing role helps reduce agency problems and uncertainty on behalf of the lenders and reduces but does eliminate any risk of refinancing. 


\section{References}

Abor, J. (2007). Corporate Governance and Financing Decisions of Ghanaian Listed Firms. Corporate Governance: International Journal of Business in Society, 7.

Adedeji, A. (1998). Does the Pecking Order Hypothesis Explain the Dividend Payout Ratios of Firms in the UK? Journal of Business Finance and Accounting, 25, 1127-55.

Agca, S., \& Mansi, S. (2008). Takeover Defenses, Managerial Ownership, and Firm Leverage. Journal of Financial Research, 31, 85-112. http://dx.doi.org/10.2139/ssrn.890745

Akdal, S. (2011). How do firm characteristics affect capital structure? Some UK Evidence. http://dx.doi.org/10.2139/ssrn.1775706

Al khasawneh, O. (2006). The Ownership Structure and its Impact in Determining the Structure of Capital in the Jordanian Public Shareholding Companies (2000-2003). PhD Thesis, Amman Arab University for Graduate Studies.

Al Shaher, T. (2012). The Impact of Determinants of Leverage on Capital Structure of Service Companies in Jordan. International Research Journal of Finance and Economics, 96.

Al-Najjar, B. (2011). Empirical Modelling of Capital Structure: Jordanian Evidence. Journal of Emerging Market Finance, 10(1), 1-19.

Alsadeek, A. A. (2002). Determinants of Financial Structure for Joint Stock Industrial Companies in the Kingdom of Saudi Arabia. Journal of Public Administration, 42, 723-745.

Anderson, R. (2002). Capital Structure, Firm Liquidity and Growth. Working paper, research series. National Bank of Belgium.

Anderson, R., Mansi, S. A., \& Reeb, D. M. (2003). Board Characteristics, Accounting Report Integrity, and Cost of Debt. Journal of Accounting and Economics, Forthcoming.

Ang J. (1991). Small Business Uniqueness and the Theory of Financial Management. The Journal of Small Business Finance, 1(1), 1-13.

Ang J. (1992). On the Theory of Finance for Privately Held Firms. The Journal of Small Business Finance, 1(3), 185-203.

Ang J., Chua J., \& McConnell, J. (1982). The Administrative Costs of Corporate Bankruptcy: A Note. The Journal of Finance, 37(1), 219-226.

Antoniou, A., Guney, Y., \& Paudyal, K. (2002). Determinants of Corporate Capital Structure: Evidence from European Countries. University of Durham, Working Paper, 1-8.

Baker, M., \& Stein, J. C. (2004). Market liquidity As a Sentiment Indicator. Journal of Financial Markets, 7(3), 271-299.

Barclay, M. J., \& Smith, C. W. Jr. (1999). The Capital Structure Puzzle: Another Look at the Evidence. Journal of Applied Corporate Finance, 12(1), 8-20.

Barton, S. L., Ned, C. H., \& Sundaram, S. (1989). An Empirical Test of Stakeholder Theory Predictions of Capital. Financial Management, 18(1), 36-44.

Bathala, C., Moon, K., \& Rao, R. (1994). Managerial Ownership, Debt Policy and the Impact of Institutional Holdings: An Agency Perspective. Financial Management, 23(3), 38-50.

Bennet, M., \& Donnelly, R. (1993). The Determinants of Capital Structure: Some UK Evidence. British Accounting Review, 25, 43-59.

Berger, A., \& Udell, G. (1992). Some Evidence on the Empirical Significance of Credit rationing. Journal of Political Economy, 100(5), 1047-1077.

Berger, A., \& Udell, G. (1995). Relationship Lending and Lines of Credit in Small Firm Finance. Journal of Business, 68(3), 351-381. http://dx.doi.org/10.2139/ssrn.124708

Berger, P., Ofek, E., \& Yermack, D. (1997). Managerial Entrenchment and Capital Structure Decisions. Journal of Finance, 52(4), 1411-1438.

Bevan, A., \& Danbolt, J. (2000). Dynamics in the determinants of capital structure in the UK. Working Paper. University of Glasgow. 
Bevan, A., \& Danbolt, J. (2002). Capital Structure and its Determinants in the United Kingdom: A Decompositional Analysis. Mimeo. Department of Accounting and Finance, University of Glasgow.

Bevan, A., \& Danbolt, J. (2002). Capital Structure and Its Determinants in the UK - A Decomposition Analysis. Applied Financial Economics, 12, 159-170. http://dx.doi.org/10.2139/ssrn.233550

Bhaduri, S. (2002). Determinants of Corporate Borrowing: Some Evidence from the Indian Corporate Structure. Journal of Economics and Finance, 26(2), 200-215.

Booth, L., Aivazian, V., Demirguc-Kunt, A., \& Maksimovic, V. (2001). Capital structures in developing countries. Journal of Finance, 14(1), 87-130. http://dx.doi.org/10.1111/0022-1082.00320

Bradley, M., Jarrel, G. A., \& Kim, E. H. (1984). On the existence of an optimal capital structure: Theory and evidence. Journal of Finance, 39(3), 857-880. http://dx.doi.org/10.1111/j.1540-6261.1984.tb03680.x

Buferna, F., Bangassa, K., \& Hodgkinson, L. (2005). Determinants of Capital Structure: Evidence from Libya. University of Liverpool. Working Paper, 2-7.

Campbell, K., \& Jerzemowska, M. (2001). Capital Structure Decisions Made by Companies in a Transitional Economy. In D. Zarzecki (Ed.), Financial management, objectives-organisation-tools (pp. 51-76). Warszawa: Fundacja Rozwoju Rachunkowości w Polsce.

Cardone, C., Longarela, I. R., \& Camino, D. (1998). Capital Market Inefficiencies, Credit Rationing and Lending Relationship in SME's. Business Economics Series. Universidad Carlos III de Madrid.

Cassar, G., \& Holmes, S. (2003). Capital Structure and Financing of SMEs: Australian Evidence. Accounting and Finance, 43, 123-147.

Chaganti, R., \& Damanpour, F. (1991). Institutional Ownership, Capital Structure and Firm Performance. Strategic Management Journal, 12(7), 479-493.

Chang, C. (1987). Capital Structure as Optimal Contracts. Working Paper. Carlson School of Management, University of Minnesota.

Chen, C., \& Steiner, T. (1999). Managerial Ownership and Agency Conflicts: A Nonlinear Simultaneous Equation Analysis of Managerial Ownership, Risk Taking, Debt Policy and Dividend Policy. Financial Review, 34(1), 119-136.

Chen, J., \& Roger, S. (2005). The Determinants of Capital Structure: Evidence from Chinese Listed Companies. Economic Change and Restructuring, 38, 11-35.

Chiarella, C., Toan, M. P., Ah, B. S., \& Madeleine, M. L. T. (1991). Determinants of Corporate Capital Structure: Australian Evidence. Working Paper Series, 3. School of Finance and Economics, University of Technology, Sydney.

Chittenden, F., Hall, G., \& Hutchinson, P. (1996). Small Firm Growth, Access to Capital Markets and Financial Structure: Review of Issues and an Empirical Investigation. Small Business Economics, 8, 59-67.

Coase, R. (1937). The Nature of the Firm. Economica, 4, 386-405.

Coles, J. L., Daniel, N. D., \& Naveen, L. (2008). Boards: Does one size fit all? Journal of Financial Economics, $87,329-356$.

Daskalakis, N. Y., \& Psillaki, M. (2008). Are the Determinants of Capital Structure Country or Firm Specific? Evidence from SMEs. Small Business Economics, 33(3), 319-333.

Deranieh, R. (1992). Determinants of Financial Structure in Jordanian Industrial Companies. Master Thesis. Amman Arab University for Graduate Studies.

Donaldson, G. (1961). Corporate Debt Capacity: A Study of Corporate Debt Policy and the Determination of Corporate Debt Capacity. Harvard Graduate School of Business Administration. Division of Research, Harvard University, Boston.

Drever, M., \& Hutchinson, P. (2007). Industry Differences in the Determinants of the Liquidity of Australian Small and Medium Sized Enterprises. Small Enterprise Research, 15(1), 60-76.

Drobetz, W., \& Roger, F. (2003). What are the determinants of the Capital Structure? Some Evidence for Switzerland. Working Paper. University of Basel.

Faleye, O. (2004). Does One Hat Fit All? The Case of Corporate Leadership Structure. Working Paper. College of Business Administration, North-eastern University, Boston, MA. 
Fama, E. F., \& French, K. (2002). Testing Tradeoff and Pecking Order predictions about Dividends and Debt. The Review of Financial Studies, 15, 1-33. http://dx.doi.org/10.2139/ssrn.199431

Fattouh, B., Laurence, H., \& Pasquale, S. (2004). Non-Linearity in the Determinants of Capital Structure: Evidence from UK firms. Centre for Financial and Management Studies. SOAS, University of London. http://dx.doi.org/10.1007/s00181-007-0128-3

Ferri, M. G., \& Jones, W. H. (1979). Determinants of Financial Structure: A New Methodological Approach. Journal of Finance, 34(3), 631-644.

Fosberg, R. H. (2004). Agency Problems and Debt Financing: Leadership Structure Effects. Corporate Governance. International Journal of Business in Society, 4(1), 31-38.

Frielinghaus, A., Mostert, B., \& Firer, C. (2005). Capital Structure and the Firm's Life Stage. South Africa Journal of Business Management, 36(4), 9-18.

Friend, I., \& Hasbrouck, J. (1988). Determinants of Capital Structure. Research in Finance. New York, JAI Press.

Friend, I., \& Lang, L. (1988). An Empirical test of the Managerial Self-Interest on Corporate Capital Structure. Journal of Finance, 43(2), 271-281.

Gajdka, J. (2002). Teorie struktury kapitatu i ich aplikacja w warunkach polskich (1st ed.). Łódź: Wydawnictwo Uniwersytetu Łódzkiego.

Gleason, K., Mathur, L., \& Mathur, I. (2000). The Interrelationship between Culture, Capital Structure, and Performance: Evidence from European Retailers. Journal of Business Research, 50, 185-191.

Graham, J., \& Harvey, C. (2001). The Theory and Practice of Corporate Finance: Evidence from the Field. Journal of Financial Economics, 60, 187-243. http://dx.doi.org/10.2139/ssrn.220251

Grier, P., \& Zychowicz, E. (1994). Institutional Investors, Corporate Discipline and the Role of Debt. Journal of Economics and Business, 46(1), 1-11.

Grossman, S., \& Hart, O. (1982). Corporate Financial Structure and Managerial Incentives. In J. J. McCall (Ed.), The Economics of Information and Uncertainty (pp. 107-140). Chicago: University of Chicago Press.

Hall, G., Hutchinson, P., \& Michaelas, N. (2000). Industry Effects on the Determinants of Unquoted SMEs' Capital Structure. International Journal of the Economics of Business, 7(3), 297-312.

Hall, G., Hutchinson, P., \& Michaelas, N. (2004). Determinants of the Capital Structure of European SMEs. Journal of Business Finance and Accounting, 31(5), 711-728.

Harris, M., \& Raviv, A. (1991). The Theory of Capital Structure. Journal of Finance, 46, 297-356. http://dx.doi.org/10.2307/2328697

Hasan, A., Muhammad A., \& Safdar, A. B. (2009). The Impact of Ownership Structure and Corporate Governance on Capital Structure on Pakistani Listed Companies. International Journal of Business and Management, $4(2)$.

Higgs Report. (2003). A More Important Role for Non-executive Directors. Freshfields, Bruckhaus Designer. Retrieved from http://www.ecgi.org/codes/documents/higgsreport.pdf

Holz, C. A. (2002). The Impact of the Liability-Asset Ratio on Profitability in China's Industrial State-Owned Enterprises. China Economic Review, 13, 1-26.

Hovakimian, A., Opler, T., \& Titman, S. (2001). The Debt-Equity Choice. Journal of Financial and Quantitative Analysis, 36, 1-24.

Huang, S., \& Song, F. (2002). The Determinants of Capital Structure: Evidence from China. Working Paper. The University of Hong Kong.

Hutchinson, P. (2004). How Much Does Growth Determine Capital Structure? Small Enterprise Research, 12, 81-92.

Hutchinson, P., Hall, G., \& Michaelas, N. (1998). The Determinants of Capital Structure for Micro, Small and Medium Sized Enterprises. International Council for Small Business, Conference Proceedings. Singapore.

Jensen, M. (1986). Agency Costs of Free Cash Flow, Corporate Finance and Takeovers. American Economic Review, 76, 323-339. http://dx.doi.org/10.1016/0304-405X(76)90026-X

Jensen, M., \& Meckling, W. (1976). Theory of the Firm: Managerial Behavior, Agency Costs and Ownership 
Structure. Journal of Financial Economics, 3, 305-60. http://dx.doi.org/10.2139/ssrn.94043

Jõeveer, K. (2005). What Do We Know About The Capital Structure of Small Firms? Working Paper Series. Prague, December.

Jordan, J., Lowe, J., \& Taylor, P. (1998). Strategy and Financial Policy in UK Small Firms'. Journal of Business Finance \& Accounting, 25, 1-27.

Karmel, S. M., \& Bryon, J. (2002). A Comparison of Small and Medium Sized Enterprises in Europe and in the USA (Routledge).

Kharawish, A. H. (2008). The Determinants of the Capital Structure Evidence from Jordanian Industrial Companies. JKAU: Econ. \& Adm., 24(1), 173-196.

Kim, C. S., Mauer, D. C., \& Sherman, A. E. (1998). The Determinants of Corporate Liquidity: Theory and Evidence. Journal of Financial and Quantitative Analysis, 33, 335-359.

Lee, J. (2010). Institutional change: Asian corporate governance and finance.

Leland, H. E., \& Pyle, D. H. (1977). Information Asymmetries, Financial Structure and Financial Intermediation. The Journal of Finance, 32(2).

Lipson, M. L., \& Mortal, S. (2009). Liquidity and Capital Structure. Journal of Financial Markets, 12(4), 611-644. http://dx.doi.org/10.1016/j.nmar.2009.04.002

Long, M., \& Malitz, I. (1985). Investment Patterns and Gearing. In Friedman, M. B. (Eds.), Corporate Capital Structure in the United States. Chicago and London: The University of Chicago Press.

Manawaduge, A., Zoysa, A. D., \& Rudkin, K. (2009). Performance Implication of Ownership Structure and Ownership Concentration: Evidence from Sri Lankan Firms. Performance Management Association Conference (pp. 1-12). Dunedin, New Zealand: Performance Measurement Association.

Martin, S., Eichenbaum, L. P. H., \& Kenneth, J. S. (1988). A Time Series Analysis of Representative Agent Models of Consumption and Leisure Choice under Uncertainty. The Quarterly Journal of Economics, 103(1), 51-78.

McConnell, J. J., \& Pettit, R. R. (1984). Application of the Modern Theory of Finance to Small Business Firms. In P. M. Horvitz \& R. R. Pettit (Eds.), Small Business Finance. Greenwich, Connecticut: JAI Press.

Mehran, H. (1992). Executive Incentive Plans, Corporate Control, and Capital Structure. Journal of Financial and Quantitative Analysis, 27(4).

Michaelas, N., Chittenden, F., \& Poutziouris. P. (1999). Financial policy and capital structure choice in UK SMEs: Empirical evidence from company panel data. Small Business Economics, 12, 113-130. http://dx.doi.org/10.1023/A:1008010724051

Miller, M. H. (1977). Debt and Taxes. Journal of Finance, 32, 261-275.

Mira, F. S. (2001). On the Capital Structure of Small and Medium Enterprises: The Spanish Case. Jurídicas Y De La Comunicación, Universidad Cardenal Herrera-Ceu. http://dx.doi.org/10.2139/ssrn.277090

Modigliani, F., \& Miller, M. (1958). The Cost of Capital, Corporation Finance and the Theory of Investment. American Economic Review, 48, 261-297.

Myers, S. C. (1977). Determinants of Corporate Borrowing. Journal of Financial Economics, 5, 147-175. http://dx.doi.org/10.1016/0304-405X(77)90015-0

Myers, S. C. (1984). The Capital Structure Puzzle. Journal of Finance, 39, 575-592. http://dx.doi.org/10.2307/2327916

Myers, S. C. (2001). Capital Structure. Journal of Economic Perspectives, 15(2), 81-102.

Myers, S. C., \& Pogue, G. A. (1974). A Programming Approach to Corporate Financial Management. Journal of Finance.

Myers, S., \& Majluf, N. (1984). Corporate Financing and Investment Decisions When Firms Have Information that Investors Do Not Have. Journal of Financial Economics, 13, 187-221. http://dx.doi.org/10.1016/0304-405X(84)90023-0

Omet, G., \& Nobanee, H. (2001). The Capital Structure of Listed Industrial Companies in Jordan. Arabic Journal of Administrative Sciences, 8, 273-289. 
Opler, T., Pinkowitz, L., Stulz, R., \& Williamson, R. (1999). The Determinants and Implications of Corporate Cash Holdings. Journal of Financial Economics, 52, 3-46.

Ozkan, A. (2001). Determinants of Capital Structure and Adjustment to Long Run Target: Evidence from UK Company Panel Data. Journal of Business Finance \& Accounting, 28(1/2), 175-198.

Pandey, I. (2001). Corporate Dividend Policy and Behaviour. The Malaysian Experience, Working Paper. Ahmadabad: Indian Institute of Management.

Petersen, M., \& Rajan, R. (1994). The Benefits of Lending Relationships: Evidence from Small Business Data. 21 Journal of Finance, 49(1), 3-37.

Petersen, M., \& Rajan, R. (1995). The effect of the credit market competition on lending relationships. Quarterly Journal of Economics, 407-443.

Pettit, R., \& Singer, R. (1985). Small Business Finance: A Research Agenda. Financial Management, 14(3), 47-60.

Pfeffer, J. (1973). Size, Composition and Function of Corporate Boards of Directors: The Organisation-environment linkage. Administrative Science Quarterly, 18, 349-364.

Pfeffer, J., \& Salancick, G. R. (1978). The External Control of Organisations: A Resource-dependence Perspective. New York: Harper \& Row.

Psillaki, M., \& Mondello, G. (1996). Financing Small and Medium Sized Firms: Coordination and Transaction Costs. Cahiers Monnaie et Financement, 24.

Pushner, G. M. (1995). Equity Ownership Structure, Leverage, and Productivity: Empirical evidence from Japan. Pacific-Basin Finance Journal, 3(2-3), 241-255.

Rajan, R. G., \& Zingales, L. (1995). What Do We Know About Capital Structure? Some Evidence from International Date. Journal of Finance, 1421-1459.

Ross, G. C. (1977). The Determination of Financial Structure: The Incentive Signalling Approach. Bell Journal of Economics \& Management Science (Spring), 23-40.

Šarlija, N., \& Harc, M. (2012). The impact of liquidity on the capital structure: A case study of Croatian firms. Business Systems Research, 3(1), 30-36.

Schoubben, F., \& Hulle, C. V. (2004). The Determinants of Leverage: Differences between Quoted and Non Quoted Firms. Tijdschrift voor Economie en Management, 589-621.

Scott, J. (1976). A Theory of Optimal Capital Structure. The Bell Journal of Economics, 34, 33-54.

Scott, J. (1977). Bankruptcy, Secured Debt, and Optimal Capital Structure. Journal of Finance, 32, 1-20.

Shlash, S., Ali, A. B., \& Salem, A. (2006). The Determinants of Financial Structure in the Business Companies; Applied Case of Jordanian Public Shareholding Companies Listed on Amman Stock Exchange for the Period (1997-2001). Al-Manara, 14(1).

Smith, C. W., \& Warner, R. L. (1979). On Financial Contracting: An Analysis of Bond Covenants. Journal of Financial Economics, 7(2), 117-161.

Soumadi, M., \& Hayajneh, O. S. (2012). Capital Structure and Corporate Performance Empirical Study on the Public Jordanian Shareholdings Firms Listed in the Amman Stock Market. European Scientific Journal, $8(22)$.

Subadar, U. A., Lamport, M., \& Bhujoo-Hosany, W. (2010). Theories of Capital Structure: Evidence from Investment and Non-investment Firms Listed on the Stock Exchange of Mauritius.

Sukkari, A. (2003). The Determinants of the Capital Structure in the Kuwaiti Capital Market. Master Thesis, The Hashemite University, Amman, Jordan.

Titman, S., \& Wessels, R. (1988). The Determinants of Capital Structure Choice. Journal of Finance, 1-19. http://dx.doi.org/10.1111/j.1540-6261.1988.tb02585.x

Tong, S., \& Ning, Y. (2004). Does Capital Structure Affect Institutional Investor Choices? The Journal of Investing, 13(4), 53-66.

Van Wijst, D. (1989). Financial Structure in Small Business: Theory, Tests and Applications. Lecture notes in economics and mathematical systems. 
Van Wijst, N., \& Thurik, R. (1993). Determinants of Small Firm Debt Ratios: An Analysis of Retail Panel Data. Small Business Economics, 5, 55-65. http://dx.doi.org/10.1007/BF01539318

Voulgaris, E., Asteriou, D., \& Agiomirgianakis, G. (2004). Size and Determinants of Capital Structure in the Greek Manufacturing Sector. International Review of Applied Economics, 18(2), 247-262.

Wald, J. (1999). How Firm Characteristics Affect Capital Structure: An International Comparison. J. Financial Res., 22, 161-187.

Wallalage, H. H., \& Stuart, L. (2012). Corporate Governance and Capital Structure Decision of Sri Lankan Listed Firms. Global Review of Business and Economic Research, 8(1), 157-169.

Warner, J. (1977). Bankruptcy Costs: Some Evidence. The Journal of Finance, 32(2), 337-347.

Wen, Y., Rwegasira, K., \& Bilderbeek, J. (2002). Corporate Governance and Capital Structure Decisions of Chinese Listed Firms. Corporate Governance: An International Review, 10(2), 75-83. http://dx.doi.org/10.1111/1467-8683.00271

Weston, J., Butler, A., \& Grullon, G. (2005). Stock Market Liquidity and the Cost of Issuing Equity. Journal of Financial and Quantitative Analysis, 40, 331-348.

Williamson, O. (1975). The Economic Institutions of Capitalism. New York: Free Press.

Zeitun, R., \& Tian, G. G. (2007). Capital Structure and Corporate Performance: Evidence from Jordan. Australasian Accounting Business and Finance Journal, 1(4).

Zingales, L. (2000). In Search of New Foundations. Journal of Finance, 15(4), 1623-1653.

\section{Notes}

Note 1. Martin et al. (1988) reviewed the debt capacity theories developed by different scholars during the 1970 's and concluded that the value of a firm is maximised when the marginal benefit of debt is equal to the marginal cost of debt.

Note 2. They used 10 developing countries, namely India, Pakistan, Thailand, Malaysia, Zimbabwe, Mexico, Brazil, Turkey, Jordan and Korea.

Note 3. For instance, if a firm retains larger investments in land, equipment and other tangible assets, it will have smaller costs of financial distress than a firm which relies upon intangible assets.

Note 4. Moreover, Jensen and Meckling (1976), Myers (1977) and Myers and Majluf (1984) further argue that collateralization is an important feature of debt covenant, and also indicate to a positive relationship between tangibility and a firm's leverage.

Note 5. Grossman and Hart (1982) argued that managers are adverse to bankruptcy because to its effect on compensation plans and job security.

Note 6. Van de Wijst and Thurik (1993), Chittenden et al. (1996), Barclay and Smith (1999) and Bevan and Danbolt (2000), claim that any analysis of leverage determinants based only on total liabilities may screen the important differences between long-term and short-term debt.

Note 7. For example, see Bennet and Donnelly, (1993);Van der Wijst and Thurik, (1993); Rajan and Zingales, (1995); Chittenden et al., (1996); Hutchinson et al., (1998); Jordan et al. (1998); Hall et al. (2000); Cassar and Holmes (2003); Drobetz and Fix (2003); Jõeveer (2005); and Fattouh et al. (2008).

Note 8. Bradley et al. (1984); Titman and Wessels (1988); Barton et al (1989); Chittenden et al (1996); Hall et al. (1996); Michaelas et al. (1998); Hall et al. (2004); Voulgaris et al. (2004); Drever and Hutchinson (2007); Zeitun and Tian, (2007); Hasan and Butt, (2009); Al-Najjar, (2011); Wellalage and Locke (2012).

\section{Copyrights}

Copyright for this article is retained by the author(s), with first publication rights granted to the journal.

This is an open-access article distributed under the terms and conditions of the Creative Commons Attribution license (http://creativecommons.org/licenses/by/3.0/). 